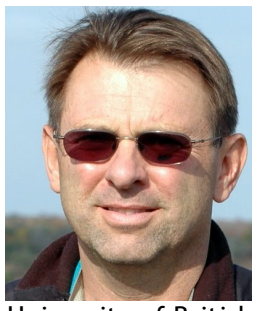

\title{
SOME REFLECTIONS ON THE RESOLUTION OF STATE- TO-STATE DISPUTES IN INTERNATIONAL WATERS GOVERNANCE AGREEMENTS
}

Richard Kyle Paisley

Director, Global Transboundary International

Waters Governance Initiative at the Institute of Asian Research, University of British Columbia, Vancouver, Canada

\author{
Alex Grzybowski \\ Pacific Resolutions, \\ Victoria, British \\ Columbia, Canada
}

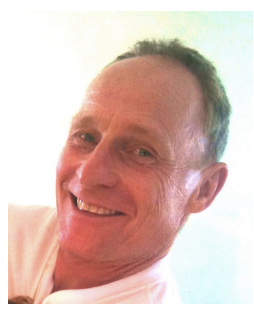

This paper reviews various dispute resolution mechanisms that have, or may have, application in international waters governance agreements. International waters are water resources that are shared by two or more states. They include international freshwater, international groundwater and international Large Marine Ecosystem (LMEs) situations. There are a number of possible types of dispute resolution mechanisms in international waters governance agreements. They include: (1) international courts, such as the International Court of Justice; (2) standing regional courts and tribunals, such as the Southern African Development Community (SADC) Tribunal; and (3) ad hoc arbitration, such as arbitrations administered by the Permanent Court of Arbitration. While no one type of dispute resolution mechanism is suitable for all states in all situations, some of the objectives that may be sought in dispute resolution in international waters governance agreements arguably include: (1) obtaining an effective remedy; (2) obtaining a correct result and (3) maximizing the efficiency, in terms of cost and/or timing, of the decision-making process. Having an efficacious dispute resolution enforcement mechanism in an international waters governance agreement may help ensure that a state can obtain an effective remedy even when an opposing state fails to voluntarily comply with a decision in a timely manner. Providing for an enforcement mechanism in an international waters governance agreement may also help encourage voluntary compliance as it may move states to consider the costs of non-compliance.

\section{Introduction $^{1}$}

There is nothing more difficult to take in hand, more perilous to conduct, or more uncertain in its success, than to take the lead in the introduction of a new order of things. For the reformer has enemies in all those who profit by the old order, and only lukewarm defenders in all those who would profit by the new order, this lukewarmness arising partly from fear of their adversaries ... and partly from the incredulity of mankind, who do not truly believe in anything new until they have had actual experience of it.

Niccolo Machiavelli, The Prince (1535)

\footnotetext{
1 This paper draws, with permission, on materials originally compiled by Lauren Mandell and Andreas Menaker of the international law firm White \& Case for a colloquium on dispute resolution and international waters in Almaty, Kazakhstan, in December 2010, organised by the United Nations Regional Centre for Preventive Diplomacy for Central Asia in Ashgabat, Turkmenistan. Also gratefully acknowledged in the production of this paper is the support and encouragement of Paul Martin and Miriam Verbeek at the University of New England School of Law in Armidale, Australia as well as Glen Hearns, Susan Bazilli, Hilary Norris, Theressa Etmanski and Maaria Curlier of the Global Transboundary International Waters Governance Initiative. Also gratefully acknowledged are the materials compiled by White \& Case and the Global Transboundary International Waters Governance Initiative and published by the United Nations Development Programme entitled 'International Waters: Review of Legal and Institutional Frameworks'.
} 
This paper critically reviews various dispute resolution mechanisms that have, or may have, application in the context of agreements dealing with governance of international waters. For the purposes of this paper international waters are defined as water resources that are shared by two or more states. They include international freshwater, international groundwater and international Large Marine Ecosystems (LMEs) situations. ${ }^{2}$

Good governance of international waters is critically important not only to protect and promote sustainability but also to help ensure security throughout entire regions. ${ }^{3}$ Agreements regarding the governance of international waters tend to stabilise and enhance security at the regional level, and the security return generated may be independent of the concrete ecological and economic benefits produced by such agreements. ${ }^{4}$

\section{According to Kraska:}

The role of transboundary river agreements in promoting sustainable development extends beyond simple economic and environmental factors. In South Asia, agreements have helped to strengthen political ties. The agreements have value as vehicles to ameliorate tension and reduce the likelihood of war. Although freshwater rivers, especially transnational ones, are frequently understood to contribute to international conflict, in South Asia the process and results of concluding transboundary river agreements have had positive ripple effects on the regional security environment. ${ }^{5}$

Joint cooperation around international watercourses may essentially pave the way for enhanced regional cooperation in other domains of politics, economics, environment and culture. Regrettably, states do not always have the confidence that commitments will be maintained and joint or coordinated investments will be safe. ${ }^{6}$ One key element of good governance, which may increase such confidence, is an effective dispute resolution mechanism. Arguably, such mechanisms not only increase the confidence that commitments will be fulfilled but also provide a more secure foundation for consideration and development of more substantial commitments. ${ }^{7}$ This is certainly true in the case international freshwater situations and arguably also true in international groundwater and international marine (LME) situations. ${ }^{8}$

\footnotetext{
The most salient international law agreement as pertains to international freshwater, even though not yet formally entered into force, is that which was concluded under United Nations auspices in 1997, and is entitled the United Nations Convention on the Law of the Non-navigational Uses of International Watercourses, opened for signature 21 May 1997, GA Res SI/229 (not yet in force). The emerging law of transboundary aquifers is reflected in the United Nations, Draft Articles on the Law of Transboundary Aquifers, UN GAOR 63 ${ }^{\text {rd }}$ sess, Supp No 10, UN Doc A/63/10, art 2 (2008). Large Marine Ecosystems (LMEs) are relatively large ocean areas - approximately $200000 \mathrm{~km}^{2}$ or greater - adjacent to continents, and characterised by distinct bathymetry, hydrography, productivity and trophic relationships. Based on these criteria, 64 distinct LMEs have been identified around the coastal boundaries of the Atlantic, Indian and Pacific Oceans. As they encompass coastal areas, LMEs are sites of high productivity, producing about $80 \%$ of the annual world's marine fisheries, but are also centres of significant biodiversity loss, coastal ocean pollution and nutrient over enrichment, habitat degradation and overfishing. See: NOAA, ‘LME Introduction’ at <http: / / www.Ime.noaa.gov/index.php?option=com_content\&view=article\&id=47\& $\mid$ temid=41>. See also: David Downes and Braden Penhoet, Center for International Environmental Law, Effective Dispute Resolution: A Review of Options For Dispute Resolution Mechanisms and Procedures, prepared for the Fifth Session of the Multilateral High-Level Conference on the Conservation and Management of Highly Migratory Fish Stocks in the Western and Central Pacific. Prepared by the Center for International Environmental Law for the World Wildlife Fund-US, September, 1999 , in which it is stated that '[i]n designing dispute resolution mechanisms and procedures, negotiators do not have to start with a blank slate. They will be guided by the goals of the negotiation, as well as the substantive principles of the 1982 United Nations Convention on the Law of the Sea (UNCLOS) and the 1994 United Nations Agreement on Highly Migratory and Straddling Fish Stocks (SSA). Equally important, they will be working within the flexible procedural framework for dispute resolution established by the UNCLOS and the SSA ... Finally, they can draw on lessons learned from the experience with international dispute settlement, not only in the area of high seas fisheries but in other areas of international law.'

3 James Kraska, 'Sustainable Development is Security: the Role of Transboundary River Agreements as Confidence Building Measure (CBM) in South Asia’ (2003) 28 Yale Journal of International Law 465.

4 Ibid.

5 Ibid.

6 Ibid.

7 Ibid.

8 A Duda and K Sherman, 'A New Imperative For Improving Management of Large Marine Ecosystems' (2002) 45 Ocean and Coastal Management 797.
} 


\section{Designing an effective dispute resolution mechanism}

The settlement of disputes between states is only one facet of the enormous problem of the general maintenance of international peace and security. ${ }^{9}$ There is no obligation in general international law to settle disputes, and procedures of settlement by formal and legal procedures rest on the consent of the parties. ${ }^{10}$

Systematic and effective dispute resolution mechanisms in international waters governance agreements can arguably:

- Reinforce proactive problem solving and dispute prevention

- Facilitate the resolution of disputes based on facts

- Utilise human and financial resources of riparian states as efficiently and effectively as possible

- Reduce the risks associated with cooperative management and investment

- Expand the potential for mutual gain

Dispute resolution mechanisms in international waters agreements are arguably best structured as a sequence of progressively more intensive steps or elements, each of which contributes to achieving these underlying objectives: procedures to clarify facts; negotiation; mediation; and binding dispute resolution (including binding arbitration and binding adjudication).

These elements are mutually reinforcing. Clarification of the facts is needed to determine the scope of the actual dispute, which is essential to negotiation, mediation and binding dispute resolution, and separates misunderstandings from the realities of the situation. The prospect of binding dispute resolution may also reinforce incentives to negotiate a solution.

\section{Figure 1: Dispute Resolution Sequence ${ }^{11}$}

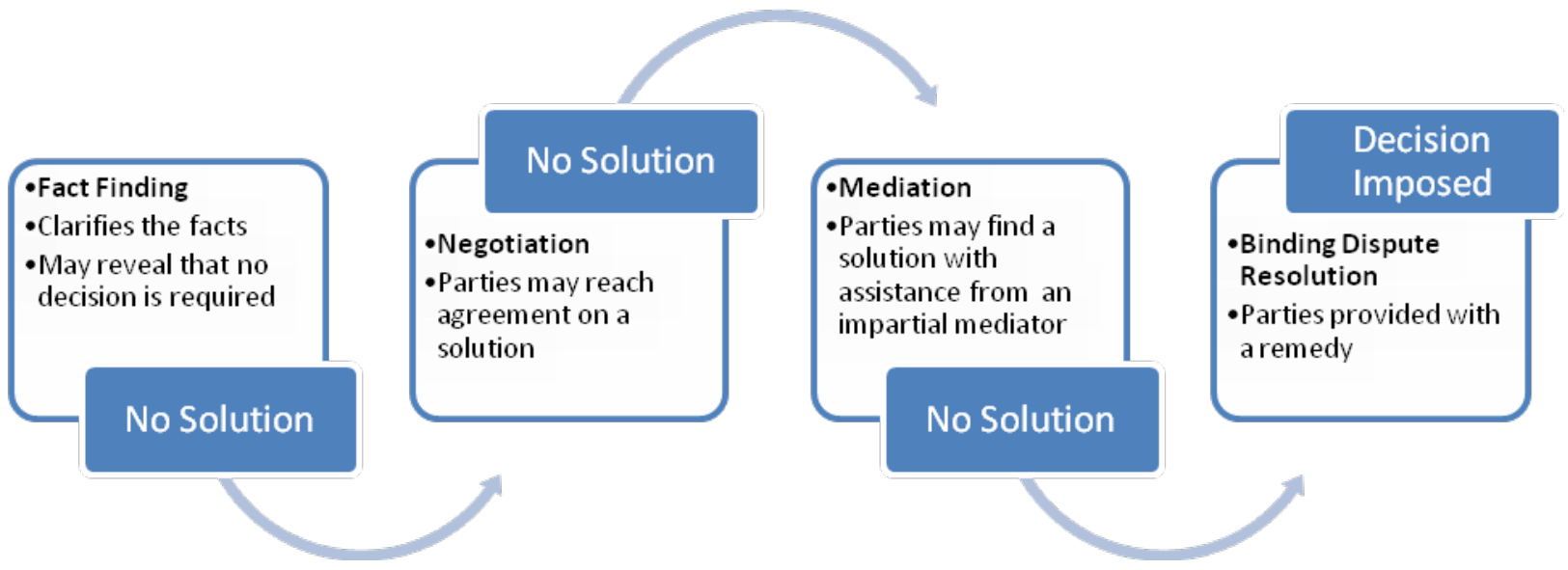

Each of the elements outlined in Figure 1 contributes to resolving disputes in a different manner. ${ }^{12}$ When they are combined in a systematic manner, the weaknesses of the individual

\footnotetext{
${ }^{9}$ Ian Brownlie, Principles of Public International Law (Oxford University Press, $8^{\text {th }}$ ed, 2008) 701.

${ }^{10}$ Ibid.

${ }^{11}$ Adapted from materials presented by Alex Grzybowski at a colloquium in Almaty, Kazakhstan, December 2010, organized by the United Nations Regional Centre for Preventative Diplomacy in Central Asia.
} 
elements may be addressed and the strengths may be combined to create an effective dispute resolution mechanism.

\section{Fact finding}

Fact finding procedures can often be a key element in dispute resolution mechanisms for international waters agreements. ${ }^{13}$

For example, the 1997 UN Watercourses Convention includes a binding commitment to establish a Fact Finding Commission to investigate a dispute between parties to the Convention. ${ }^{14}$ In the event that the parties to the dispute disagree on the composition of a Fact Commission, the Secretary General of the United Nations is empowered to decide on the composition of the Commission.

Another example is that prior to agreeing on the Columbia River Treaty, Canada and the United States were in conflict over the construction of infrastructure on the Columbia River. ${ }^{15}$ However, an International Joint Commission (established to resolve boundary water disputes) undertook a key fact-finding initiative that was instrumental to the negotiation of the Columbia River Treaty. ${ }^{16}$

\section{Negotiation}

Negotiation is the most common provision in a dispute resolution mechanism in an international waters context. ${ }^{17}$ It commits the parties to attempt to resolve disputes by agreement. Alone, a commitment to negotiation does not provide any certainty to the parties that disputes will be resolved because in the absence of agreement there is no resolution imposed and the dispute will persist. When this occurs it undermines the confidence of the parties and may cause them to withdraw their commitments, undermining the agreement as a whole. Negotiation is the primary vehicle that is used both to develop international water agreements and to make decisions regarding implementation of these agreements. ${ }^{18}$

\section{Mediation}

Mediation is dispute resolution that is assisted by an impartial individual or organisation that assists the parties in reaching an agreement. Mediators are not empowered to resolve the dispute. However, by working with the parties independently and together, mediators are able to help the parties identify and evaluate potential solutions. Where parties have difficulty working together, or they need to be able to develop and explore potential solutions, mediators may propose ideas for consideration. These proposals may be presented to the parties collectively or mediators may shuttle proposals and counter proposals between parties. Mediation is often in-

${ }^{12}$ Adapted from materials presented by Alex Grzybowski at a colloquium in Almaty, Kazakhstan, in December 2010, organized by the United Nations Regional Centre for Preventative Diplomacy in Central Asia.

${ }^{13}$ See Eyal Benvenisti, 'Collective Action in the Utilization of Shared Freshwater: The Challenges of International Water Resources Law' (1996) 90 American Journal of International Law 384, 402, stating that '[w]ith the shared language of technical expertise, political constraints may be sidestepped and well-founded decisions more easily reached' and citing as authority the Agreement on the Establishment of a Permanent Water Commission Namibia-South Africa, signed 14 September 1992, 32 ILM 1147, 1150 which established a joint commission to serve as a technical adviser to the state parties by, inter alia, gathering data and recommending criteria to be adopted in the allocation and utilisation of common water resources.

${ }^{14}$ Convention on the Law of the Non-navigational Uses of International Watercourses (Watercourses Convention), opened for signature 21 May 1997, GA Res 51/229 (not yet in force).

${ }^{15}$ Treaty Relating to Cooperative Development of the Water Resources of the Columbia River Basin (Columbia River Treaty), United States-Canada, signed 17 January 1964, 542 UNTS 244. See also: Alex Grzybowski, Stephen C McCaffrey and Richard Kyle Paisley, 'Beyond International Water Law: Successfully Negotiating Mutually Beneficial Agreements for International Watercourses' (2010) 22 Pacific McGeorge Global Business \& Development Law Journal 139.

16 lbid.

${ }^{17}$ See UNDP-GEF, International Waters: Review of Legal and Institutional Frameworks, (International Waters Project, 2011).

${ }^{18}$ Ibid. 
cluded as an optional step in dispute resolution provisions in international water agreements, and it has been instrumental in the development of a number of challenging agreements such as the Indus Waters Treaty between Pakistan and India ${ }^{19}$ and the 1995 Mekong Agreement between the lower four Mekong States. ${ }^{20}$

\section{Binding dispute resolution}

Binding dispute resolution is often the final stage in the process of dispute resolution. By agreement of the parties, a single decision-maker or a panel of decision-makers hears the parties' arguments, reviews evidence and issues a binding decision which may not be appealed. There are three primary types of binding dispute resolution mechanisms for resolving state-to-state disputes: (1) international courts, such as the International Court of Justice (ICJ); (2) standing regional courts and tribunals, such as the Southern African Development Community Tribunal (SADCT); and (3) ad hoc arbitration, such as arbitrations administered by the Permanent Court of Arbitration (PCA). ${ }^{21}$ Each of these mechanisms has various advantages and disadvantages depending on the nature of the dispute and the interests of the parties. For example, one mechanism may promise a speedy resolution of the dispute, but may be costly to administer. Another mechanism may allow the parties to choose the decision-makers, but may be less predictable and consistent. However, all three mechanisms have been used to resolve territorial and water disputes. In 2010, for instance, the ICJ rendered a decision in a high-profile dispute between Argentina and Uruguay over Uruguay's construction of industrial facilities on the banks of a river shared by the two States. ${ }^{22}$ The Court's decision, holding that the construction did not violate a 1975 Treaty between the States, has generally been well received by the States and the international community.

\section{Enforcement ${ }^{23}$}

The outcomes of negotiation, mediation and binding dispute resolution need to be implemented if the parties are to have any confidence in the dispute resolution mechanism. What assures implementation? This varies depending on the means used to resolve the dispute. The underlying guarantees of implementation are the prospect of binding dispute resolution and withdrawal of the benefits associated with the cooperation.

Where states are committed to binding dispute resolution they may be obligated under customary international law to comply with the decision. States, nonetheless, may wish to choose a binding dispute resolution mechanism that offers additional incentives for compliance and/or penalties for non-compliance. At the IJC, parties have a right to bring an enforcement issue to the United Nation Security Council. At the regional and ad hoc level, some states have agreed to give the United Nations or other neutral third parties a role in enforcement, and others have created more novel tools. For example, some states have required the parties in an arbitration to contribute funds to a security account that will be used to pay a judgment rendered by the tribunal. The Iran-United States Claims Tribunal is one such example. ${ }^{24}$ Some states also have tied the benefits of regional associations to which the states belong to compliance with decisions. For example, in the Southern African Development Community (SADC), a failure to comply with a

\footnotetext{
19 The Indus Waters Treaty 1960, India-Pakistan, signed 19 September 1960, International Bank for Reconstruction and Development art V \& X, and annex F, G\& H.

20 The Mekong River Commission, 1995 Mekong River Agreement and Procedural Rules, <http://www.mrcmekong.org/download/agreement95/agreement_procedure.pdf >.

${ }^{21}$ Loretta Malintoppi, 'Methods of Dispute Resolution Inter-State Litigation: When States Go To Arbitration Rather Than Adjuducation' (2006) 5 The Law and Practice of International Courts and Tribunals 133.

${ }^{22}$ Pulp Mills on the River Uruguay (Argentina v Uruguay) (Judgment of 2- April 2010) [2010] ICJ <http: //www.icjcij.org/docket/files/135/15895.pdf>.

${ }^{23}$ ECE/UNEP Network of Experts on Public Participation and Compliance, 'Water Management: Convention on Protection and Use of Transboundary Watercourses and International Lakes: Guidance on Public Participation and Compliance with Agreements' (2000).

${ }^{24}$ Iran-US Claims Tribunal <http://www.iusct.org/>.
} 
tribunal decision will be referred to the policy-making arm of the Community, which may choose to suspend or withdraw the benefits of the delinquent state, including benefits related to regional trade and investment. ${ }^{25}$ Another example is the situation with regard to the 1992 Agreement between Central Asian States which includes art 12 which made reference to developing economic measures for violations against the agreed water regime and limits of use. ${ }^{26}$

Fact finding, negotiation, mediation and binding dispute resolution can also be combined to create powerful dispute resolution mechanisms that will strengthen international waters governance agreements. The prospect of such mechanisms may also provide the confidence that parties need in order to seriously consider more substantial commitments and cooperative development initiatives that can yield the potential benefits of cooperation on international waters governance. ${ }^{27}$

\section{Survey of binding dispute resolution mechanisms}

The essential feature of binding dispute resolution in an international waters context is that a third party issues a decision that the parties agree in advance to respect and comply with. To reach a decision, the third party decision-maker typically hears arguments from the parties and reviews evidence.

\section{Benefits}

There are several benefits to having a binding dispute resolution mechanism in an international water agreement. ${ }^{28}$ The mechanism provides a means for resolving disputes that may arise in the future. It also may provide benefits even if a dispute never arises, or if the parties choose not use the mechanism when a dispute does arise. ${ }^{29}$

Having a binding dispute resolution mechanism in place may also assist the parties in reaching agreement at the treaty negotiation stage. In international treaty negotiations, parties on all sides must make commitments. Parties will be inclined to make commitments only if they believe that the other parties' commitments are meaningful and that there will be negative consequences for a failure to comply. Having a binding dispute resolution provision is useful because negotiating parties will take into consideration that a decision-maker with the power to issue binding decisions will enforce commitments.

After the treaty is negotiated and concluded, the existence of a binding dispute resolution option encourages the implementation of treaty commitments. Parties may be less likely to defy a treaty if they face the prospect of a binding decision issued against them.

In many cases, once a dispute arises and before binding dispute resolution is invoked, the parties may engage various dispute resolution methods, including fact-finding, negotiation and/or mediation.

For example, the Convention for the Protection and Development of the Marine Environment of the Wider Caribbean Region (Cartagena Convention or Convention) was adopted in Cartagena, Colombia in 1983 and entered into force in $1986 .{ }^{30}$ The Convention calls upon the Contracting

\footnotetext{
${ }^{25}$ The Treaty Of The Southern African Development Community, opened for signature 17 August 1992, <http://www.sadc.int/index/browse/page/120>.

${ }^{26}$ Agreement between the Republic of Kazakhstan, the Republic of Kyrgyzstan, the Republic of Uzbekistan, and the Republic of Tajikistan and Turkmenistan on the Cooperation in the Field of Joint Water Resources Management and Conservation of Interstate Resources, signed and entered into force 18 February 1992.

${ }^{27}$ Kraska, above $\mathrm{n} 4$.

${ }^{28}$ Loretta Malintoppi, 'Methods of Dispute Resolution Inter-State Litigation: When States Go To Arbitration Rather Than Adjuducation' (2006) 5 The Law and Practice of International Courts and Tribunals 133.

${ }^{29}$ Kraska, above $\mathrm{n} 4$.

${ }^{30}$ Convention for the Protection and Development of the Marine Environment of the Wider Caribbean Region, The Final Act of the Conference of the Plenipotentiaries on the Protection and Development of the Marine Environment of the
} 
Parties to settle any disputes concerning the interpretation or application of the Convention or its Protocols through negotiations or other peaceful means. If these means of dispute resolution fail, the parties may agree to submit the dispute to arbitration as set forth in the Annex to the Convention. ${ }^{31}$ According to the Annex to the Cartagena Convention that governs the terms of arbitration, arbitral tribunals shall consist of three members. Each party to the dispute may appoint an arbitrator, and the arbitrators will, by agreement, designate a third arbitrator, who will serve as chairman of the tribunal. The chairman of the tribunal cannot be a national of either of the parties to the dispute. If a party refuses to appoint an arbitrator, or if appointed arbitrators cannot agree on a chairman, the Secretary-General of the United Nations can appoint the arbitrator(s) necessary to constitute the tribunal. The arbitral tribunal must render its decision in accordance with international law and the provisions of the Cartagena Convention and the relevant Protocol(s). Decisions are made by majority vote. The tribunal must issue an award within five months of its constitution, unless it requires additional time in which case it may extend the time limit for up to five additional months. The decision of the arbitral tribunal is final and binding upon the parties to the dispute. ${ }^{32}$

Another example is in the case of the Columbia River Treaty (CRT) where Article XVI of the Columbia River Treaty provides that a dispute or difference that arises under the Treaty may be referred by either the United States or Canada to the IJC for a decision. If the IJC does not render a decision within three months of the referral, or within such other period as may be agreed upon by the United States and Canada, either country may submit the dispute to arbitration by providing written notice to the other country. The Columbia River Treaty mandates that arbitration must be by a tribunal composed of a member appointed by Canada, a member appointed by the United States and a member appointed jointly by the United States and Canada who shall be Chairman. If within six weeks of the delivery of a notice of arbitration, either country has failed to appoint its member to the arbitral tribunal, or they are unable to agree upon the member who is to be Chairman, either the United States or Canada may request that the President of the International Court of Justice appoint the member(s). Decisions of the IJC or of an arbitration tribunal (by a majority of members) are binding and definitive on the parties. The United States and Canada may agree, by an exchange of notes, to use alternative procedures for settling differences arising under the Columbia River Treaty, including referring disputes to the International IJC for a decision. ${ }^{33}$

The existence of a binding dispute resolution provision in the treaty arguably enhances the effectiveness of these other dispute resolution mechanisms. Without it, a party could refuse to participate in good faith in the other mechanisms without facing consequences. If a binding dispute resolution procedure looms, parties may take these other dispute resolution methods more seriously. This may produce faster settlements and a less acrimonious dispute resolution process. For example, since the signing of the Columbia River Treaty, there has yet to be a dispute on the Columbia River that has required the use of arbitration.

Binding dispute resolutions provide parties with the means to resolve their disputes definitively. If the dispute reaches binding dispute resolution, the decision of the third party decision-maker will be recognized as binding by the international community. Perhaps for this reason, a high percentage of decisions of international binding dispute resolutions mechanisms have been complied with by states. ${ }^{34}$

Wider Caribbean Region ('Cartagena Convention'), opened for signature 24 March 1983, entered into force 11 October 1986; The Caribbean Environment Programme ('CEP')-Cartagena Convention \& Protocols.

${ }^{31}$ See, Cartagena Convention, above n 30art 23: 'a Contracting Party may notify the Depositary that, in relation to any other Contracting Party who accepts the same obligation, it will abide by, without special agreement, the procedures listed in the Annex'.

${ }^{32}$ Cartagena Convention, annex arts 3-6, 10. According to art 8 of the Annex, the expenses for the arbitral tribunal are equally divided between the parties to the dispute.

${ }^{33}$ Columbia River Treaty, above n 15, art XVI.

${ }^{34}$ Aloysius Llamzon, 'Jurisdiction and Compliance in Recent Decisions of the International Court of Justice' (2007) 18 European Journal of International Law 815. 


\section{Types of binding dispute resolution mechanisms}

There are various types of binding dispute resolution mechanisms that are potentially available in an international waters governance context. They include: (1) global mechanisms (2) regional mechanisms and (3) dispute-specific mechanisms.

Global mechanisms are theoretically available for all states to use to resolve disputes concerning specified subject matters. The most prominent example is the ICJ, seated at the Peace Palace in The Hague. It was created in 1945 as the judicial organ of the United Nations to resolve disputes of a general nature between states that have consented to its jurisdiction. ${ }^{35}$ Other examples include the International Criminal Court ${ }^{36}$ ('ICJ') and the International Tribunal for the Law of the Sea. ${ }^{37}$ The ICJ has a long and distinguished history of resolving disputes between states involving international waters. The ICJ is composed of 15 judges who are elected by the United Nations General Assembly and the United Nations Security Council to nine-year terms. The ICJ's rules of procedure are codified in the Statute of the International Court of Justice, an annex to the United Nations Charter. Its official languages are English and French.

Regional mechanisms resolve specific types of disputes involving parties in the same region, as well as situations where more than one dispute arises out a particular event. Should sovereign states choose to have their disputes resolved by a regional mechanism, they would need to create one either by drafting a regional water treaty containing a binding dispute resolution provision, or by grafting a binding dispute resolution provision onto an existing regional treaty. SADC features an example of the latter. ${ }^{38}$ The SADC, a 15-state regional bloc focused on trade, development and security, established a tribunal in 1992 to issue binding decisions to resolve disputes involving the interpretation of the SADC treaty and its protocols. ${ }^{39}$ In 1998, SADC members enacted a protocol on shared water bodies and referred all disputes involving the protocol to the SADC tribunal. ${ }^{40}$ Another prominent example of an interesting regional mechanism with possible application in an international waters context is the Iran-United States Claims Tribunal. ${ }^{41}$ The Iran-United States Claims Tribunal is composed of nine judges - three Iranian, three United States and three non-nationals - seated at The Hague who render binding decisions in disputes between Iran, the United States and their nationals arising from the Iranian Revolution.

Dispute-specific mechanisms are another option for binding dispute resolution. By creating a dispute-specific mechanism in a treaty, states agree in advance on a procedure to choose decision-makers (typically three to five decision-makers) when a dispute arises, as well as the procedural rules and law that will guide the proceedings. There is no standing body of decisionmakers that hears all disputes arising out of the treaty, as is typical for global and regional mechanisms. Dispute-specific dispute resolution often takes the form of arbitration. For each dispute that arises under the treaty, a distinct arbitral panel would be constituted to hear and decide that particular dispute. Arbitration may be 'administered' meaning that an arbitral institution provides certain assistance to the arbitrators and the parties, or it may be ad hoc, in which case it is not administered under the auspices of any arbitral institution.

\footnotetext{
${ }^{35}$ See International Court of Justice <http://www.icj-cij.org/homepage/index.php>.

${ }^{36}$ See International Criminal Court <http://www.icc-cpi.int/Menus/ICC?lan=en-GB>.

${ }^{37}$ See International Tribunal for the Law of the Sea < http://www.itlos.org/index.php?id=2\&L=0 >.

${ }^{38}$ SADC, Years of Progress <http://www.sadc.int/index/browse/page/715\#>; Muna Ndulo, African Integration Schemes: A Case Study of the Southern African Development Community (Cornell Law Faculty Publication, 1999) 8-11. SADCC was formed with the adoption of the Lusaka Declaration on Economic Liberation on 1 April 1980. The founding countries of SADCC were Angola, Botswana, Lesotho, Malawi, Mozambique, Swaziland, Tanzania, Zambia and Zimbabwe (with Namibia joining SADCC in 1989). The original Declaration and Treaty of the Southern Africa Development Community is available at <http://www.sadc.int/index/browse/page/119>; See The Treaty of the Southern African Development Community (SADC Treaty), above n 25, and the Revised Protocol on Shared Watercourses (Watercourses Protocol), arts. 2, 16, 7 Aug. 2000, <http://www.sadc.int/index/browse/page/159.

39 Ibid.

40 Ibid.

${ }^{41}$ See Iran-United States Claims Tribunal <http://www.iusct.org/>.
} 
Arbitrations involving state parties often are typically administered by the PCA. ${ }^{42}$ The PCA provides facilities for use in arbitrations, model rules of procedure and numerous secretarial and substantive services. Established in 1899, the PCA is experienced in administering arbitrations involving both state and non-state parties, including disputes involving territorial boundaries. Even in ad hoc arbitrations, the parties may make use of the PCA's model procedural rules, such as the PCA Optional Rules for Arbitrating Disputes Between States. ${ }^{43}$

\section{Illustrative ICJ decisions}

The decisions which follow are illustrative of recent ICJ decisions in the international waters area.

In Pulp Mills on the River Uruguay (2010), Argentina challenged Uruguay's construction of two pulp mills on the banks of the River Uruguay, which forms the boundary between the two states. ${ }^{44}$ Argentina alleged that the construction of the pulp mills violated numerous provisions of a 1975 treaty between the States, including the obligation to contribute to the optimum and rational utilisation of the river, the obligation to coordinate measures to preserve the ecological balance and the obligation to prevent pollution. Argentina also argued that Uruguay failed to give advance notice of its construction plans in violation of the procedural provisions of the treaty. Argentina requested that the Court declare Uruguay to be in breach and order Uruguay to stop construction of one mill, dismantle the second mill, pay damages and provide guarantees that it would comply with the treaty in the future. The Court denied the requested relief, reasoning that notwithstanding Uruguay's failure to inform, notify and negotiate with Argentina as required by the treaty, Argentina failed to show a substantive violation of the treaty. To reach that conclusion, the Court closely examined expert submissions from both sides regarding the environmental impact of the pulp mills.

The Case Concerning the Dispute Regarding Navigational and Related Rights (2009) concerned the interpretation of an 1858 treaty that granted Nicaragua sovereignty over the San Juan River, a natural border between Nicaragua and Costa Rica, but granted Costa Rica the right of free navigation for purposes of commerce. ${ }^{45}$ Costa Rica alleged that Nicaragua violated the treaty by denying it free navigation in at least nine ways, including, for example, by requiring passengers on Costa Rican vessels to carry Nicaraguan visas. Costa Rica sought declaratory, injunctive and monetary relief. The Court reaffirmed Nicaragua's sovereignty over the river, but held that Nicaragua's practice of requiring Costa Rican passengers to carry Nicaraguan visas, charging Costa Rican vessels special taxes and interfering with Costa Ricans' subsistence fishing along the banks of the river violated the treaty. The Court denied all other requests for relief.

The Case Relating to the Gabčíkovo-Nagymaros Project (1997) concerned the interpretation of a 1977 treaty between Hungary and Czechoslovakia to construct a system of locks on the Danube River. ${ }^{46}$ After Hungary unilaterally suspended - and then abandoned - work on the project, Czechoslovakia proceeded to dam a portion of the river on its own. Hungary and Slovakia (which succeeded to Czechoslovakia's rights and obligations under the treaty) executed a special agreement to refer the dispute to the Court. The Court declared that Hungary violated the treaty, and that, while Slovakia was within its rights to prepare an alternative means to dam the river, it breached the agreement by putting its solution into operation unilaterally. As to future conduct, the Court ordered the parties to negotiate in good faith to achieve the objectives of the treaty. The Court added that the parties should take evolving international environmental norms into

\footnotetext{
${ }^{42}$ See Permanent Court of Arbitration <http://www.pca-cpa.org/showpage.asp?pag_id=363> .

${ }^{43}$ See Permanent Court of Arbitration, Optional Rules for Arbitrating Disputes between Two States <http://www.pcacpa.org/upload/files/2STATENG.pdf>.

${ }^{44}$ Pulp Mills on the River Uruguay, above $\mathrm{n} 22$.

${ }^{45}$ See Dispute Regarding Navigational and Related Rights (Costa Rica v Nicaragua) [Judgment of 13 July 2009) [2009] ICJ $<$ http: //www.icj-cij.org/docket/index.php?p1=3\&p2=3\&k=37\&case=133\& code=coni\&p3=5>.

${ }^{46}$ See Gabčíkovo-Nagymaros Project (Hungary/Slovakia) (judgment of 1325 September 1997) [1997] ICJ <http: //www.icj-cij.org/docket/index.php?p1=3\&p2=3\&k=8d\&case=92\&code=hs\&p3=5> .
} 
account, as it recognised that the project might cause environmental harm and that the treaty required the States to consider these norms.

\section{Illustrative decisions of other global and regional mechanisms}

The decisions which follow are illustrative of recent decisions of other global and regional mechanisms with possible application to the international waters area.

In the Southern Bluefin Tuna Cases (1999), Australia and New Zealand requested that the International Tribunal for the Law of the Sea find that Japan's experimental fishing program violated its international legal obligation to preserve southern bluefin tuna. ${ }^{47}$ Pending the Tribunal's final decision, Australia and New Zealand moved for the temporary suspension of Japan's fishing program as a provisional measure. The Tribunal ordered the provisional measure on the basis of the precautionary principle. The provisional measure remained effective for 11 months until the Tribunal issued a final decision denying Australia's and New Zealand's claim for lack of jurisdiction.

In The Matter between Campbell et al v The Republic of Zimbabwe (2008), Mike Campbell, a white farmer in Zimbabwe, requested that the SADC Tribunal find Zimbabwe's seizure of his land pursuant to Amendment 17 of the Zimbabwean Constitution violated the SADC treaty. ${ }^{48}$ The Tribunal ruled that Amendment 17 violated the SADC treaty because it made the acquisition of white farmers' land immune from judicial review and discriminated against white farmers and ordered Zimbabwe to stop interfering with white farmers' land under Amendment 17 and to pay compensation to farmers who had lost their land on that basis.

\section{Illustrative decisions of dispute-specific mechanisms}

The decisions which follow are illustrative of recent decisions of dispute-specific mechanisms with possible application to the international waters area.

In Abyei, a five-member tribunal in an arbitration administered by the PCA, heard a boundary dispute between the Government of Sudan (Government) and the Sudan People's Liberation Army (SPLA). ${ }^{49}$ The arbitration was the culmination of 20 years of civil war between the north and south of Sudan. In 2005, the Government and the SPLA, a powerful southern faction, signed a peace agreement which created a commission to fix the boundaries of the oil-rich Abyei province. After the Government rejected the commission's findings, the parties agreed in July 2008 to arbitrate under the PCA Optional Rules for Arbitrating Disputes Between States. In July 2009, the tribunal issued its decision, finding that the commission exceeded its mandate in drawing Abyei's northern, eastern and southern boundaries. The tribunal re-drew those boundaries.

The Ethiopia v Eritrea arbitrations, administered by the PCA, also took place against the backdrop of civil war. ${ }^{50}$ In 2000, the states created a five-member boundary commission to resolve the status of the disputed Badme territory and the boundaries between the two states and a five-member claims commission to determine damages from the armed conflict. In 2002, the boundary commission held that the Badme territory was a part of Eritrea and it demarcated boundaries in 2007. In 2009, the claims commission awarded damages.

\footnotetext{
${ }^{47}$ See International Tribunal for the Law of the Sea, Southern Bluefin Tuna Cases <http://www.itlos.org/start2_en.html>.

${ }^{48}$ See Southern African Development Community Tribunal, The Matter between Campbell et al v The Republic of Zimbabwe <http: //www.sadc-tribunal.org/docs/case032009.pdf>.

${ }^{49}$ See Permanent Court of Arbitration, The Government of Sudan/The Sudan People's Liberation Movement/Army (Abyei Arbitration) <http://www.pca-cpa.org/showpage.asp?pag_id=1306>.

${ }^{50}$ Permanent Court of Arbitration, Eritrea-Ethiopia Claims Commission <http://www.pcacpa.org/showpage.asp?pag_id=1151>.
} 


\section{Choosing a binding dispute resolution mechanism}

While no one type of binding dispute resolution mechanism is suitable for all states in all situations, objectives that may be sought with respect to a binding dispute resolution mechanism include: (1) obtaining an effective remedy (2) obtaining a correct decision and (3) maximizing the efficiency, in terms of cost and time, of the decision-making process. ${ }^{51}$

To determine which mechanisms may be appropriate to resolve disputes in particular international waters situations, states are advised to scrutinise the ICJ, regional mechanisms and dispute-specific mechanisms in terms of these objectives along with any other objectives that may be of importance to them.

Each of these possible objectives is discussed below.

\section{Obtaining an effective remedy}

To provide an effective remedy, a binding dispute resolution mechanism should arguably provide: (1) meaningful relief (2) incentives for voluntary compliance with decisions and (3) means to enforce decisions where voluntary compliance is not forthcoming. ${ }^{52}$ These are discussed below.

\section{Meaningful relief}

In international practice, an award in favour of a state can consist of an order to pay monetary compensation, an injunction (an order to perform certain action), or a declaratory judgment (a statement of the rights and obligations of the parties), or a combination of these. A provisional order, which is an order for a party or parties to take certain action pending further consideration by the decision-makers at the conclusion of the proceedings, may also be an element of meaningful relief.

The ICJ typically issues declaratory judgments. ${ }^{53}$ Injunctions are infrequently issued and an award of monetary compensation is extremely rare. By contrast, regional and dispute-specific bodies may order monetary compensation or injunctive relief depending on the unique features of each mechanism and their rules of procedure. All three types of dispute resolution bodies may issue provisional orders.

\section{Incentives for voluntary compliance ${ }^{54}$}

Compliance with a decision of a binding dispute resolution mechanism is an international legal obligation. Global, regional and dispute-specific mechanisms have a variety of methods to help compel states to comply with international legal obligations. However, because states are sovereign actors, the means to compel states to comply with international decisions are limited.

Therefore, it is important for a dispute resolution mechanism to create incentives for voluntary compliance. ${ }^{55}$

For example, the ICJ has several aspects that may promote voluntary compliance. First, the obligation to comply with ICJ decisions is written into the UN Charter. Second, the Court has a unique international public profile because it is composed of leading judges and has issued frequently cited decisions in dozens of significant cases. Third, the parties' pleadings and the Court's decisions are made publicly available after a case ends, increasing the likelihood that a state's non-compliance will receive international attention.

For regional mechanisms, the role that states play in establishing and maintaining the body may promote compliance with that body's decisions. For example, where the regional mechanism

\footnotetext{
${ }^{51}$ Malintoppi, above $\mathrm{n} 28$.

52 Ibid.

${ }^{53}$ See ICJ, above n 36.

${ }^{54}$ See ECE/UNEP Network of Expert on Public Participation and Compliance, above n 23.

${ }^{55}$ Ibid.
} 
plays an ongoing role in the state parties' relationships, as is the case with the SADC, this may promote compliance with the regional mechanism's decisions. Similarly, because the same regional body will be called upon to decide future disputes, where any non-complying state may need to seek the assistance of that regional body, states may have an added incentive to comply with the decisions of regional mechanisms. As for dispute-specific mechanisms, the role states play in choosing decision-makers for a particular dispute may increase the likelihood of voluntary compliance with a decision. In the case of both regional and dispute-specific mechanisms, the visibility of a particular dispute may affect voluntary compliance.

For regional and dispute-specific mechanisms, the pleadings and decisions may well remain confidential, unless there is agreement by the states in the treaty or at a later time to make them public. For example, in the Abyei arbitration the parties chose to make the pleadings and decisions public, and then went further and posted hours of video from the proceedings on the internet.

\section{Enforceability ${ }^{56}$}

In situations where a state delays or refuses to comply with a binding decision, a dispute resolution mechanism's ability to enforce the decision may become critical.

With respect to decisions issued by the ICJ, a state has a right to request that the UN Security Council make recommendations or enact measures to aid the enforcement of an ICJ decision. ${ }^{57}$

Existing regional and dispute-specific mechanisms offer several models of enforcement. For example, at the SADC, the Tribunal shall report any failure to comply with a decision to the Summit, the SADC's supreme body, which has the authority to issue sanctions, including the withdrawal of benefits enjoyed by the state as a result of its SADC membership. ${ }^{58}$ Another example is in the case of the Iran-United States Claims Tribunal where Iran is required to place funds in a security account and maintain a minimum balance to be used to pay any awards issued against it. ${ }^{59}$ As for dispute-specific mechanisms, in the Ethiopia $v$ Eritrea arbitration, the boundary commission requested that the United Nations assist in enforcement of the new boundaries. ${ }^{60}$

\section{Obtaining a correct result}

To increase the likelihood that the binding dispute resolution mechanism provides a 'correct' result, several factors should, arguably, be considered, including (1) the expertise of the decision-makers (2) the impartiality of the decision-makers and (3) the predictability or consistency of decisions. ${ }^{61}$

\footnotetext{
${ }^{56}$ ECE/UNEP Network of Expert on Public Participation and Compliance, above $\mathrm{n} 23$.

${ }^{57}$ ICJ, How the Court Works <http://www.icj-cij.org/court/index.php?p1=1\&p2=6>.

See also Llamzon, above n 34 :

This clearly manifests the strong link between the ICJ and the Security Council as institutions with related but decidedly different competencies in the settlement of international disputes - the ICJ is tasked with allocating rights and responsibilities and assessing competing legal claims among states party, and the Security Council is tasked, upon judgment, to give effect to that decision, should the debtor state refuse to comply.

A number of subtle points are discernible from the text: first, only 'judgments' of the ICJ are subject to Article 94 enforcement. Secondly, only the judgment creditor state has the right to seek recourse from the Security Council; this was not the case with the League of Nations and Permanent Court. Thirdly, the Security Council appears to retain discretion both as to whether it shall act to enforce at all and, if so, what concrete measures it decides to take. Clearly, therefore, the enforcement of ICJ judgments involves quintessentially political acts by both parties and the Security Council, in which the Court itself has little involvement and over which it has no power.

${ }^{58}$ See The Treaty Of The SADC, above $\mathrm{n} 25$.

${ }^{59}$ See Iran-United States Claims Tribunal, above n 41.

${ }^{60}$ See The Treaty $O f$ The SADC, above $\mathrm{n} 25$.

${ }^{61}$ The International Bureau of the Permanent Court of Arbitration (ed), 'Resolution of International Water Disputes' (Papers presented at the Sixth PCA International Law Seminar, 8 November 2002).
} 


\section{Expertise of decision-makers}

In State-to-State disputes concerning the interpretation of treaty rights and obligations, the decision-makers' expertise in international law, including the rules concerning treaty interpretation, may affect the correctness of a decision. Therefore, in the context of disputes over international waters, states need to consider whether it is important to them to have decisionmakers who have expertise in hydrology or in regional issues. For example the courts in the United States have pioneered the use of 'special masters'. In the case of the ICJ, the judges at the ICJ are prominent experts in international law who are selected to reflect the diversity of the world's legal systems. ${ }^{62} \mathrm{ICJ}$ judges are experienced in resolving disputes involving transboundary water bodies, though they are not necessarily experts in hydrology or engineering. Very often, parties will engage experts when arguing a case before the ICJ or before another dispute resolution body. In terms of regional expertise, if no sitting judge is a national of a state that is party to a case, the state may appoint a national as judge ad hoc to take part in the consideration of the matter and the rendering of a decision.

With respect to both regional and dispute-specific mechanisms, states may determine the desired qualifications of the decision-makers. For example, the SADC requires that judges be accomplished jurists or highest-level civil servants. ${ }^{63}$ While the governing documents of the IranUnited States Claims Tribunal and the Abyei and Ethiopia v Eritrea arbitrations do not state minimum qualifications for decision-makers, in practice the decision-makers have included former ICJ judges as well as prominent academics and practitioners. ${ }^{64}$ Decision-makers in a regional mechanism may decide all disputes arising under the treaty. Therefore they tend to be more expert with regard to individual treaties than ICJ judges or arbitrators - who may be called upon to decide only one specific dispute arising out of that treaty - in a dispute-specific mechanism.

\section{Impartiality of decision-makers}

It is important to ensure that decision-makers with the power to issue a binding decision are impartial. Having decision-makers who are nationals of the states that are party to the dispute or of other interested states may present at least the appearance of partiality. On the other hand, states may deem such risks to be outweighed by the need to ensure that the decisionmakers have sufficient knowledge of regional issues. One of the most important decisions states must consider in deciding upon a dispute resolution mechanism is what role they wish to play in appointing decision-makers and whether the appointment of party nationals would make a correct decision less likely because of concerns regarding the decision-makers' partiality or the increased likelihood that the decision-making process will become politicised.

For regional and dispute-specific mechanisms, states may determine the desired rules concerning the nationality of decision-makers. In the SADC Tribunal rules and in the agreements establishing the Abyei and Ethiopia $v$ Eritrea arbitrations, there are no nationality provisions. ${ }^{65}$ Nonetheless, in the Abyei and Ethiopia $v$ Eritrea arbitrations, the parties did not select party nationals as arbitrators. The Iran-United States Claims Tribunal requires that the nine-member full tribunal consist of three United States nationals, three Iranian nationals, and three non-nationals and that smaller three-member chambers consist of one United States national, one Iranian national and one non-national. ${ }^{66}$

\footnotetext{
${ }^{62}$ See ICJ, above n 36.

${ }^{63}$ See The Treaty Of SADC, above $\mathrm{n} 25$.

${ }^{64}$ See The International Bureau of the Permanent Court of Arbitration (ed), above n 62. In the Gabčíkovo-Nagymaros case the ICJ Judges famously visited the site of the dispute.

${ }^{65}$ See The Treaty Of The SADC, above n 25; see Iran-United States Claims Tribunal, above n 41; see Permanent Court of Arbitration, above $\mathrm{n} 51$

${ }^{66}$ See The Treaty Of The SADC, above n 25.
} 


\section{Predictability or consistency of results}

States may find it desirable for the dispute resolution mechanism to issue predictable and consistent results, which may assist states in understanding their obligations under the treaty and may even lessen the possibility of resort to the dispute resolution mechanism. A decision-maker may be more likely to reach a correct decision if the decision is informed by previous decisions. On the other hand, a decision-maker that approaches each case anew may be less likely to repeat previous errors.

The ICJ is not bound by prior decisions, but in practice the judges follow precedents stretching back to the ICJ's predecessor, the Permanent Court of International Justice. ${ }^{67}$ This yields consistency. Regional mechanisms also tend to produce consistent results as the same body hears multiple disputes arising out of the same treaty. However, if the caseload of a regional dispute mechanism becomes great, the regional mechanism may need to develop a system whereby the full body only hears a portion of the cases and the remaining cases are heard by smaller panels. In bodies that employ this system, such as the Iran-United States Claims Tribunal, the decision of the smaller panels or chambers do not bind the full tribunal or future panels and inconsistencies between the decisions of different panels or chambers may arise. For dispute-specific mechanisms, there is potentially no consistency because a new tribunal is constituted for each dispute and prior decisions rendered by other tribunals are not binding. As a matter of practice, however, a tribunal may choose to rely on earlier decisions rendered by other ad hoc tribunals that have interpreted the same treaty.

\section{Efficiency}

There are at least three aspects of efficiency in binding dispute resolution that may arguably be relevant in an international waters context: (1) the cost of establishing the dispute resolution mechanism (2) the cost of resolving a dispute through the dispute resolution mechanism and (3) resolving the dispute in a timely manner. ${ }^{68}$

\section{Cost of establishing the dispute resolution mechanism}

While there is no formal cost involved in submitting a dispute to the ICJ, choosing to submit disputes to a regional dispute resolution mechanism typically entails significant up-front costs as it is likely to require considerable time, money and effort to establish the necessary regional body. ${ }^{69}$ These costs are lessened if states choose to submit their disputes under the treaty to a pre-existing regional body. By contrast, dispute-specific mechanisms have almost no establishment costs as the only cost involved is that connected with drafting the arbitration clause in the treaty.

\section{Costs of resolving a dispute}

At the ICJ, the expenses of the proceedings are paid for by United Nations member states' dues. ${ }^{70}$ Parties do not pay a filing fee, the judges' salaries, or administration fees. The parties, however, must bear the expense of holding hearings at The Hague, translating pleadings and evidence into English or French and making a substantial number of copies of pleadings, as required by the Court's rules. To offset these costs, states may seek assistance from the Secretary General's Trust Fund, which awards funds to states based on their financial needs and the availability of funds.

\footnotetext{
${ }^{67}$ See The Treaty Of The SADC, above $\mathrm{n} 25$.

${ }^{68}$ See Malintoppi, above $\mathrm{n} 28$.

${ }^{69}$ See ICJ, above n 36.

${ }^{70}$ Ibid.
} 
For regional mechanisms, there are potentially fewer translations and travel costs if the body is located in the region. The parties, however, must pay the decision-makers a salary or stipend and pay for dedicated hearing space and administrative support.

For dispute-specific mechanisms, like regional mechanisms, translation costs and travel costs vary. ${ }^{71}$ Unlike a regional body, the states may choose to site an arbitration outside of the region out of concern for neutrality - as was done in both the Abyei and Ethiopia v Eritrea arbitrations. The parties to an arbitration must also pay for arbitrators and administration per case, generally at an hourly fee. For arbitrations that are administered by the PCA, states that meet certain objective eligibility requirements may seek financial assistance from the PCA Financial Assistance Fund. ${ }^{72}$

\section{Resolving the dispute in a timely manner}

ICJ proceedings generally take three to five years. ${ }^{73}$ The length of proceedings may be due, in part, to the great number of judges who preside over each case and the ICJ's significant caseload. The Court's ad hoc chamber or chamber of summary procedure, which would have fewer judges, may be faster, but the former has been used infrequently and the latter has never been used.

Regional and dispute-specific mechanisms generally have fewer decision-makers and a lesser caseload and the parties can prescribe, in the treaty, timing requirements for the proceedings and the issuance of judgments. In the Abyei and Eritrea $v$ Ethiopia arbitrations administered by the PCA, the parties and the tribunals abided by strict schedules which the parties had developed. ${ }^{74}$ As a result, the Abyei tribunal rendered a decision within one year and the Ethiopia $v$ Eritrea boundary commission rendered a decision within 16 months.

\section{Enforcement}

Having the means to comply with and enforce binding decisions ensures that a state can obtain an effective remedy even when the opposing state fails to voluntarily comply with a decision in a timely manner. ${ }^{75}$ Providing for enforcement may also itself encourage voluntary compliance, as it may move states to consider the costs of non-compliance. The ICJ, as well as some regional and dispute-specific mechanisms, has arguably attained high levels of compliance through a combination of incentives for voluntary compliance and methods to compel compliance.

\section{ICJ}

Compliance with ICJ decisions appears to be remarkably high. For example, statistical data indicates that States ordinarily comply with ICJ decisions. ${ }^{76}$ From 1946 to 1987, for example, 80 per cent of ICJ decisions were fully complied with. From 1987-2004, 60 per cent of decisions gained full compliance and the remainder were partially complied with. Compliance since 2004 has been viewed as consistent with historical trends. States may comply with ICJ judgments, in large part, because they want to be seen as responsible actors in the international community. Some illustrative examples are presented below.

\footnotetext{
${ }^{71}$ See the materials complied by White \& Case and published by the United Nations Development Programme entitled International Waters: Review of Legal and Institutional Frameworks <http://governance-iwlearn.org/wpcontent/uploads/2011/07/International-Waters-Report-White-and-Case.pdf>.

72 Permanent Court of Arbitration, Financial Assistance Fund as found at <http://www. pcacpa.org/showpage.asp?pag_id=1179>.

73 See ICJ, above n 36.

${ }^{74}$ See Permanent Court of Arbitration, Eritrea-Ethiopia Claims Commission <http://www.pcacpa.org/showpage.asp?pag_id=1151>.

${ }^{75}$ See Malintoppi, above n 28.

${ }^{76}$ See Llamzon, above n 34.
} 
In Pulp Mills on the River Uruguay (2010), both Argentina and Uruguay accepted the Court's decision that Uruguay's action did not violate the applicable treaty. ${ }^{77}$ In its decision, the Court noted that Uruguay was obligated to monitor the effects of the mill. Accordingly, in November 2010, the States signed an accord setting up a scientific committee composed of experts from both States to monitor the pollution levels on the river. This appears to be the end of a conflict that threatened relations between the States and which at times nearly turned violent: thousands of protestors from Argentina blocked a bridge serving the pulp mills intermittently for three years.

In the Case Relating to the Gabčíkovo-Nagymaros Project (1997), Hungary and Slovakia complied with the Court's order to negotiate to achieve the objectives of a treaty between the States calling for the joint construction of a dam on the Danube River. ${ }^{78}$

In Certain Activities Carried out by Nicaragua in the Border Area (2009), since the Court recognized Costa Rica's right to navigate the San Juan River for ordinary commercial activities, including tourism, Costa Rican officials have periodically complained that Nicaragua has disregarded the decision by demanding tolls and seizing commercial goods transported on the river. ${ }^{79}$ In November 2010, Costa Rica filed a new, separate claim against Nicaragua before the ICJ, arguing that Nicaragua has made illegal incursions into Costa Rican territory in connection with its construction of a canal off the San Juan River. Nicaragua has responded that the disputed territory is part of Nicaragua.

\section{Regional mechanisms}

The SADC and the Iran-United States Claims Tribunal are examples of two regional dispute resolution mechanisms that have adopted novel means to comply with and enforce results and therefore may have something to offer in an international waters dispute resolution context.

In 2000, the SADC ratified a protocol to promote the sustainable and equitable utilisation of shared water resources, and empowered the Tribunal to rule on disputes under the protocol as well. If a state fails to comply with a Tribunal decision regarding the treaty or the water protocol, the Tribunal shall report the non-compliance to the Summit, SADC's supreme body, which has the power to issue sanctions. In the Matter between Campbell et al $v$ The Republic of Zimbabwe (2008), the Tribunal reported Zimbabwe's non-compliance to the Summit, which has yet to take action. $^{80}$

At the Iran-United States Claims Tribunal, the treaty establishing the body provided for a US $\$ 1$ billion security account, to be created from Iran's assets frozen by the United States, to pay awards issued against Iran. ${ }^{81}$ Iran is required to maintain a minimum balance of US \$500 million and promptly make deposits if the amount falls below that figure. To date, the Tribunal has ordered Iran at least twice, in 2000 and 2004, to replenish the security account after extended periods of delinquency. Numerous awards, amounting to more than two billion dollars, have been paid out from this account. The reason why this may be important in an international water context is that it demonstrates how two erstwhile adversaries can agree on a financial mechanism that virtually compels compliance. Such a powerful compliance mechanisms is arguably conspicuous by its absence in the international water field. ${ }^{82}$

\footnotetext{
${ }_{77}$ Pulp Mills on the River Uruguay, above $\mathrm{n} 44$.

${ }^{78}$ See Gabčíkovo-Nagymaros Project, above n 46.

${ }^{79}$ See ICJ, Certain Activities Carried out by Nicaragua in the Border Area (Costa Rica v. Nicaragua) as found at http://www.icj-

cij.org/docket $/$ index.php?p1=3\&p2=3\&code=crn\&case=150\&k=ec\&PHPSESSID=8131530fabafdebbd60b6a2ddf9612d9

${ }^{80}$ See The Matter between Campbell et al $v$ The Republic of Zimbabwe, above $\mathrm{n} 48$.

81 See Iran-United States Claims Tribunal, above n 41.

${ }^{82}$ See White \& Case, above $\mathrm{n} 71$.
} 


\section{Dispute-specific mechanisms}

The Ethiopia v Eritrea boundary commission and Abyei cases are examples of interesting disputespecific dispute resolution mechanisms from an international waters dispute resolution perspective.

The Ethiopia v Eritrea boundary commission ruled in 2002 that the disputed Badme territory is part of Ethiopia and in 2007 it demarcated the boundaries. ${ }^{83}$ Despite these rulings, Ethiopia has refused to relinquish the Badme territory. In the arbitration agreement, the United Nations was tasked with assisting implementation of the Commission's decision by facilitating the resolutions of issues related to the transfer of territorial control, but the United Nations has not been in a position to act because the territory has not changed hands. As for the claims commission, it awarded Ethiopia approximately US $\$ 12.5$ million (US $\$ 174$ million minus US $\$ 161.5$ million that it was held to owe Eritrea). Afterward, Eritrea stated publicly that it accepted the decision without equivocation. $^{84}$

After the Abyei decision, which re-drew the boundaries of the disputed province, the Government of Sudan and the SPLA issued a joint communiqué stating that they would enforce the decision. The demarcation of the boundaries, however, has been delayed. Further, in July 2010, a senior advisor to the Government stated that the decision was inadequate and did not resolve the dispute. The size of the province is a key issue, as Abyei residents will vote in a referendum on whether to join southern Sudan, which held a separate referendum in January 2011 on whether to secede, and which was overwhelmingly passed. ${ }^{85}$

The lesson here for dispute resolution in an international waters governance context is that lack of an explicit enforcement mechanism in an international waters governance agreement may help discourage voluntary compliance.

\section{Conclusion}

Dispute resolution is one important element of good governance of international waters.

There are a number of possible types of dispute resolution mechanisms in international waters governance agreements. They include: (1) international courts, such as the ICJ (2) standing regional courts and tribunals, such as the SADC Tribunal; and (3) ad hoc arbitration, such as arbitrations administered by the Permanent Court of Arbitration.

Some of these mechanisms, such as the ICJ are relatively well known in the realm of dispute resolution and international waters. Others, such as dispute specific mechanisms, are less well known in the realm of dispute resolution and international waters but should be of potential interest to those with an interest in good governance of international waters.

While no one type of dispute resolution mechanism is suitable for all states in all situations, some of the objectives that may be sought in dispute resolution in international waters governance agreements arguably include: (1) obtaining an effective remedy; (2) obtaining a correct result and (3) maximising the efficiency, in terms of cost and/or timing, of the decision making process.

The historical and cultural dimensions of dispute settlement in a region and some in-depth understanding of regional differences is also enormously important.

\footnotetext{
${ }^{83}$ See Permanent Court of Arbitration, The Government of Sudan/The Sudan People's Liberation Movement/Army (Abyei Arbitration) <http://www.pca-cpa.org/showpage.asp?pag_id=1306>.

${ }^{84}$ See President Isaias Afwerki's declaration at <http: / /www.eritrea.be/old/eritrea-ethiopia-boundary.htm>.

${ }^{85}$ According to the Southern Sudan Referendum Commission, $98.8 \%$ of voters voted to secede. Voter turnout was $97.58 \%$. See <http: / /www.ssrc.sd/SSRC2/>.
} 
Having an efficacious dispute resolution enforcement mechanism in an international waters governance agreement may also help ensure that a state can obtain an effective remedy even when an opposing state fails to voluntarily comply with a decision in a timely manner.

Keywords: governance, international, water, law, dispute, resolution, court, justice, arbitration, tribunal, sea, convention, transboundary, enforcement, efficiency, compliance, mediation, negotiation 